\title{
Erratum to: Wetting and Microstructure Evolution of the $\mathrm{Sn}-\mathrm{Zn}-\mathrm{Ag} / \mathrm{Cu}$ Interface
}

Katarzyna Berent, Przemysław Fima, Tomasz Gancarz, and Janusz Pstruś

\section{Erratum to: J. of Materi Eng and Perform DOI 10.1007/s11665-014-0929-4}

Please note the correct spelling of the surname of the third author of this article.

The correct spelling is "Gancarz" (not "Ganacarz").

The online version of the original article can be found under doi:10.1007/s11665-014-0929-4.

Katarzyna Berent, Przemyslaw Fima, Tomasz Gancarz, and Janusz Pstruś, Institute of Metallurgy and Materials Science, Polish Academy of Sciences, ul. Reymonta 25, 30-059 Kraków, Poland. Contact e-mails: kasia.berent@gmail.com and k.berent@imim.pl. 